\title{
HUBUNGAN PENGETAHUAN DENGAN EFIKASI DIRI PADA CAREGIVER KELUARGA PASIEN GANGGUAN JIWA DI RSJD Dr. RM. SOEDJARWADI
}

\author{
Bayu Despriyanto Pratama ${ }^{1}$, Arif Widodo \\ ${ }^{1,2}$ Program Studi Keperawatan Fakultas Ilmu Kesehatan Universitas Muhammadiyah \\ Surakarta. J1. A. Yani, Pabelan, Kartasura, Surakarta. \\ Email: ${ }^{1}$ diemy.diery@ rocketmail.com, ${ }^{2}$ arif.widodo@ums.ac.id
}

\begin{abstract}
ABSTRAK
Istilah lain gangguan jiwa adalah psikosis. Salah satu contoh psikosis adalah skizofrenia. Skizofrenia adalah kondisi maladaptif pada psikologis dan fisiologis sehingga menjadikan perilaku seseorang terganggu. Caregiver keluarga pasien gangguan jiwa menjadi satu faktor penentu tercapai kesehatan jiwa yang maksimal. Oleh karena itu, caregiver penting memiliki pengetahuan dan efikasi diri yang bagus dalam upaya memaksimalkan memelihara kesehatan jiwa. Penelitian ini bertujuan untuk mengetahui hubungan pengetahuan dengan efikasi diri pada caregiver keluarga pasien gangguan jiwa di RSJD Dr. RM. Soedjarwadi. Objek penelitian adalah caregiver keluarga pasien gangguan jiwa yang berkunjung di bagian rawat jalan dengan jumlah sampel 95 responden. Desain penelitian menggunakan deskriptif korelatif dengan pendekatan cross sectional study. Analisis data untuk mengetahui korelasi pada penelitian menggunakan uji spearman rank (rho). Hasil penelitian menunjukkan bahwa nilai uji spearman rank berdasarkan $\mathrm{Z}$ hitung adalah 0,704 dan $p$ value 0,001 . Pengetahuan caregiver keluarga pasien gangguan jiwa di RSJD Dr. RM. Soedjarwadi adalah cukup, efikasi diri caregiver keluarga pasien gangguan jiwa di RSJD Dr. RM. Soedjarwadi adalah sedang. Ada hubungan korelasi yang signifikan pengetahuan dengan efikasi diri pada caregiver keluarga pasien gangguan jiwa di RSJD Dr. RM. Soedjarwadi.
\end{abstract}

Kata kunci: Caregiver, efikasi diri, pengetahuan, skizofrenia.

\begin{abstract}
Another term for the psychiatric disorder is psychosis. Schizophrenia, one of the psychosis, is a psychological and physiological maladaptive condition that makes a person's behavior disturbed. The family caregiver of psychiatric patients becomes a critical determinant of maximal mental health. Therefore, the good self-knowledge and efficacy of caregiver are very important to maximize the maintenance of mental health. This study aimed to determine the relationship between knowledge with self-efficacy from caregiver family from mental patients in RSJD Dr. RM. Soedjarwadi. The object of the study was the family caregiver of mental patients who visited in the outpatient with a sample of 95 respondents. The research design used was descriptive correlative with cross-sectional approach. Data
\end{abstract}


analysis to know correlation in research was using Spearman rank test (rho). The results showed that the Spearman rank test value based on the $\mathrm{Z}$ score and the p-value was 0,704 and 0.001 , respectively. Knowledge of family caregiver of mental patients in RSJD Dr. RM. Soedjarwadi was a sufficient category, then self-efficacy of family caregiver of patients mental disorders in RSJD Dr. RM. Soedjarwadi was a moderate category. There was a significant correlation between knowledge with self-efficacy of family caregiver of mental patients in RSJD Dr. RM. Soedjarwadi.

Keywords: Caregiver, self-efficacy, knowledge, schizophrenia

\section{PENDAHULUAN}

Andreasen dalam Wakhid (2013) mendefinisikan skizofrenia adalah gangguan multifaktoral perkembangan saraf dipengaruhi oleh faktor genetik dan lingkungan serta ditandai dengan gejala positif, negatif dan kognitif. Womble (2015) menuliskan pada buku Introductory Mental Health Nursing, gangguan jiwa adalah gangguan klinis yang signifikan pada kognisi individu, pengaturan emosi, atau disfungsi reflek keseharian dalam psikologis, biologis, atau perkembangan proses dasar fungsi mental.

Gordon (2010) melaporan data sensus pada tahun 2010 oleh National Institute of Mental Health (NIMH) sekitar $26,2 \%$ atau satu dari seperempat orang dewasa Amerika didiagnosis memiliki gangguan mental. Laporan hasil Riset Kesehatan Dasar menunjukkan prevalensi gangguan jiwa berat yaitu 1,7 permil di Indonesia. Provinsi Jawa Tengah (2,3 permil) berada pada urutan ke lima setelah DI Yogyakarta (2,7 permil), Aceh $(2,7$ permil), Sulawesi Selatan (2,6 permil) dan Bali (2,3 permil) (Kemenkes, 2013). Sensus rumah tangga dari Badan Pusat Statistik Provinsi Jawa Tengah menurut kabupaten/ kota pada tahun 2015 adalah sebanyak 9.247.956 dan di kota Klaten adalah sebanyak 340.944 (BPS, 2016).

Pada observasi pendahuluan yang peneliti lakukan, didapat dari keterangan
Dinas Kesehatan Kab. Klaten jumlah kunjungan pasien gangguan jiwa ke 34 Puskesmas yang ada di Klaten pada tahun 2016 adalah berjumlah 1.871. Pada catatan Rekam Medik jumlah kunjungan pasien gangguan jiwa di RSJD Dr. RM. Soedjarwadi pada tahun 2015 adalah 10.685 untuk rawat jalan, meningkat pada tahun 2016 berjumlah 1.349 untuk rawat inap dan 23.994 untuk rawat jalan, pada bulan Januari 2017 berjumlah 99 untuk rawat inap dan 2.060 untuk rawat jalan.

Saat peneliti melakukan wawancara untuk mengkaji pengetahuan dasar dan efikasi diri caregiver keluarga pasien yang berada di Poli Jiwa, didapatkan keterangan bahwa keluarga belum begitu banyak yang yakin untuk merawat sendiri atau dengan anggota keluarga. Keluarga membiarkan pasien sibuk melakukan aktivitasnya baik di rumah atau luar rumah, kecuali jika pasien sampai mengganggu, mengancam atau melukai seseorang. Pada langkah pengobatan yang keluarga lakukan pertama kali adalah membawa pasien kepada orang ahli supranatural untuk berkonsultasi. Sebagian keluarga yang peneliti kaji mengatakan lebih percaya bahwa gangguan yang dialami pasien bisa disebabkan hal-hal yang tidak bisa dijelaskan oleh ilmu pengetahuan atau sains. Mitos dan konsepsi yang salah tentang kesehatan mental seperti disebabkan faktor hereditas, tidak ada masalah, tidak ada ambisi dan pasrah 
(Dewi, 2012). Perawat bangsal mengatakan seringkali pasien yang sudah habis masa rawat inap dan bisa dijemput pulang, tetapi keluarga tidak mau menjemput dengan alasan kehidupan pasien di Rumah Sakit adalah lebih baik.

Teori Friedman dalam Ali (2010) menjelaskan tentang lima tugas keluarga dalam memelihara kesehatan, yaitu mengenal masalah, memutuskan tindakan, merawat, memodifikasi lingkungan, dan memanfaatkan fasilitas. Jadi, dalam proses pemberian terapi untuk pemulihan pada orang dengan gangguan jiwa, peran keluarga adalah penting. Kesehatan mental dipengaruhi oleh hubungan interpersonal yang sehat, khususnya di dalam keluarga (Dewi, 2012). Penyakit gangguan jiwa di masyarakat bukan fenomena untuk didebatkan penyakit mental merupakan masalah kesehatan masyarakat. Tetapi yang harus diselesaikan adalah tentang bagaimana solusi agar mampu menurunkan prevalensi dan penderitaan penyakit mental (Keyes, 2010).

Efikasi merupakan suatu keyakinan dan diiringi kepercayaan atas dasar kemampuannya, sehingga dapat melakukan sebuah kontrol dengan batasan mereka sendiri dari fungsi dan atas peristiwa (Zakeri, 2016). Sedangkan menurut Bandura dalam Perez (2011) efikasi mengacu pada suatu keyakinan bahwa individu memiliki kapasitas mereka sendiri untuk mengatur dan melaksanakan program tindakan yang diperlukan untuk menghasilkan hasil yang diinginkan. Kewajiban masyarakat memahami dan mengetahui bagaimana penatalaksanaan untuk menghadapi dan menangani seorang dengan gangguan jiwa yang berada di lingkungan masyarakat. Tetapi, sampai saat ini di wilayah negara yang sedang berkembang, untuk penatalaksanaan pada orang yang memiliki gangguan jiwa belum mencapai kepuasan serta keberhasilan. Hal tersebut terjadi karena ketidaktahuan oleh suatu keluarga ataupun oleh masyarakatnya (Yaqin, 2015). Oleh karena itu, untuk mencapai kepuasan serta keberhasilan pada penatalaksanaan terhadap orang yang memiliki gangguan jiwa, keluarga dan masyarakat sekitar khususnya di kota Klaten harus mampu unggul dalam pengetahuan dan intelektual.

Bersama penjelasan latar belakang masalah di atas dan melihat dari yang peneliti kumpulkan, ditambah dari berbagai sumber penelitian yang berkaitan, maka peneliti berkeinginan untuk melakukan penelitian kuantitatif di kota Klaten dan sangat memungkinkan untuk dijadikan sebagai salah satu bahan acuan pada penelitian ini yang berkaitan dengan hubungan pengetahuan dengan efikasi diri pada caregiver keluarga pasien gangguan jiwa dengan judul "Hubungan Pengetahuan dengan Efikasi Diri Pada Caregiver Keluarga Pasien Gangguan Jiwa Di RSJD Dr. RM. Soedjarwadi”.

\section{METODE PENELITIAN}

Pada penelitian ini menggunakan desain penelitian deskriptif corelatif. Deskriptif corelatif adalah desain penelitian objektif yang bertujuan menerangkan fenomena dengan bentuk deskripsi (Notoatmodjo, 2010). Teknik pengambilan data pada penelitian ini menggunakan pendekatan cross sectional study. Potong lintang adalah istilah lain cross sectional study dan didefinisikan jenis pendekatan penelitian dengan mengkaji variabel bebas dan variabel terikat pada sebuah jenjang dan waktu yang sama (Azwar, 2014).

Populasi pada penelitian ini adalah keseluruhan elemen atau subjek riset keluarga yang berkunjung pada rawat jalan RSJD Dr. RM. Soedjarwadi. Jumlah Populasi yang peneliti dapat dari data Rekam Medik pada tahun 2016 berjumlah 23.994 dan pada bulan Januari 2017 
berjumlah 2.060. Adapun besar sampel yang peneliti gunakan sejumlah 95 sampel.

\section{HASIL DAN PEMBAHASAN}

\section{Karakteristik Responden}

Hasil penelitian berdasarkan karakteristik responden dapat dilihat pada Tabel 1.

Tabel 1. Karakteristik Responden ( $\mathrm{n}=95)$

\begin{tabular}{clcc}
\hline No & Karakteristik & Frekuensi & $\begin{array}{c}\text { Persentase } \\
(\%)\end{array}$ \\
\hline 1 & Jenis Kelamin & & \\
& a. Laki-laki & 48 & 50,5 \\
& b. Perempuan & 47 & 49,5 \\
2 & Usia & & \\
& a. 18 - 40 tahun & 33 & 34,7 \\
& b. 41 - 60 tahun & 43 & 45,3 \\
& c. 61 tahun ke & 19 & 20 \\
$\quad$ atas & & \\
3 & Hubungan & & \\
& dengan pasien & & \\
& a. Ayah/Ibu & 39 & 41,1 \\
& b. Suami/Istri & 18 & 18,9 \\
& c. Anak & 7 & 7,4 \\
& d. Saudara & 15 & 15,8 \\
& e. Keluarga & 16 & 16,8 \\
& $\quad$ selain dari di & & \\
$\quad$ atas & & \\
Lama merawat & & \\
pasien & & \\
a. 3 bulan - 5 & 72 & 75,8 \\
$\quad$ tahun & & \\
b. 6 - 10 tahun & 16 & 16,8 \\
c. 11 - 18 tahun & 7 & 7,4 \\
\hline
\end{tabular}

Pembahasan tentang karakteristik responden menurut jenis kelamin pada penelitian ini adalah keluarga pasien yang mengantarkan pasien dengan gangguan jiwa di RSJD Dr. RM. Soedjarwadi sebagian besar berjenis kelamin laki-laki. Terdapat perbedaan bersifat internal dan substansial yang jelas antara laki-laki dan perempuan ditinjau dari segi fisik serta hormonal yang mempengaruhi variasi ciriciri fisik dan biologisnya. Menurut Sigmund Freud, kepribadian laki-laki dan perempuan itu sangat berbeda sesuai dengan perbedaan karakteristik fisiknya.
Karakteristik responden berjenis kelamin laki-laki lebih banyak dari responden perempuan kemungkinan bisa disebabkan laki-laki memiliki kepribadian aktif, eksploratif, agresif, ekspresif, dominan, mengarah ke publik, berjiwa kepemimpinan, dan senantiasa ingin meraih sesuatu yang lebih banyak daripada perempuan untuk menunjukkan eksistensi dirinya (Nurhayati, 2016).

Pada bagian karakteristik responden berdasarkan usia, menunjukkan bahwa sebagian besar keluarga pasien gangguan jiwa yang mengantarkan pasien gangguan jiwa di RSJD Dr. RM. Soedjarwadi berusia 41 sampai dengan 56 tahun. Hurlock (1990) menjelaskan terdapat tiga kategori tentang dewasa seseorang, yaitu usia dewasa awal, madya dan lanjut. Hal ini menandakan bahwa keluarga yang mengantarkan pasien gangguan jiwa untuk menjalani terapi sebagian besar adalah kelompok usia dewasa madya (40 - 60 tahun). Sebuah studi penelitian yang diteliti oleh Podkova (2013) menghasilkan bahwa ada keterkaitan umur seseorang dengan self-efficacy. Tetapi pada perbedaan usia muda dan usia tua, tidak ditemukan perbedaan yang jauh atau signifikan antara usia muda dan usia tua.

Pada bagian karakeristik responden berdasarkan hubungan keluarga pasien sebagai pengantar pasien gangguan jiwa di RSJD Dr. RM. Soedjarwadi sebagian besar memiliki keterkaitan atau hubungan dengan pasien sebagai ayah atau ibu pasien dan atau bisa disebut juga dengan orang tua pasien. Sebagai keluarga pasien gangguan jiwa, keluarga harus bisa berupaya untuk mengeratkan hubungan dan interaksi kepada pasien. Hal ini merupakan salah satu cara untuk menyembuhkan pasien dengan gangguan jiwa. Berdasarkan penelitian yang dilakukan oleh Wulansih et al. (2008), diperoleh hasil adanya hubungan antara sikap keluarga dengan kekambuhan pada pasien skizofrenia. Oleh karena itu, 
caregiver keluarga pada pasien gangguan jiwa harus lebih banyak menyalurkan kontribusi berupa motivasi-motivasi kepada pasien.

Pada bagian karakteristik responden berdasarkan lama melakukan perawatan kepada pasien oleh caregiver keluarga dengan pasien gangguan jiwa di RSJD Dr. RM. Soedjarwadi sebagian besar memiliki caregiver keluarga dengan kurun waktu tiga bulan sampai dengan lima tahun. Caregiver dalam pengalaman lama melakukan perawatan anggota keluarga mampu sebagai kontribusi penentu pengetahuan dan efikasi keluarga. Sebagaimana kesamaan pendapat oleh Jalaluddin (2013) yang mengatakan bahwa melalui pengalaman yang berulang-ulang individu bisa memperoleh penentu suatu pengetahuan. Yusuf (2015) juga sependapat, menjelaskan bahwa fakta-fakta berupa kabar dan dari pengalaman adalah unsur yang bisa meliputi pengetahuan seseorang. Penguasaan pengalaman (mastery experiences) adalah salah satu sumber penentu tinggi rendahnya tingkat efikasi diri (Alwisol dalam Anggai, 2015).

\section{Analisis Univariat}

\section{Pengetahuan Keluarga}

Hasil analisis univariat pengetahuan keluarga dapat dilihat pada Tabel 2.

Tabel 2. Analisis Univariat Pengetahuan Keluarga

\begin{tabular}{clcc}
\hline No & $\begin{array}{c}\text { Pengetahuan } \\
\text { keluarga }\end{array}$ & Frekuensi & $\begin{array}{c}\text { Persentase } \\
(\%)\end{array}$ \\
\hline 1 & $\begin{array}{l}\text { Pengetahuan } \\
\text { Baik }\end{array}$ & 23 & 24,2 \\
2 & $\begin{array}{l}\text { Pengetahuan } \\
\text { Cukup }\end{array}$ & 55 & 57,9 \\
3 & $\begin{array}{l}\text { Pengetahuan } \\
\text { Kurang }\end{array}$ & 17 & 17,9 \\
\hline \multicolumn{1}{c}{ Jumlah } & 95 & 100 \\
\hline
\end{tabular}

Pembahasan tentang pengetahuan keluarga pasien gangguan jiwa dengan aspek mencakup lima tugas keluarga dalam memelihara kesehatan berdasarkan teori Friedman, yaitu: 1) mengenal masalah kesehatan, 2) mengambil keputusan tentang kesehatan, 3) merawat keluarga, 4) memodifikasi lingkungan rumah, 5) memanfaatkan fasilitas kesehatan dan ditambah dengan penyebab kekambuhan skizofrenia di RSJD Dr. RM. Soedjarwadi adalah sebagian besar keluarga dengan pengetahuan yang cukup. Hal ini didasari dengan beberapa data objektif yang didapat dari analisis penelitian dan pada umumnya keluarga untuk memerankan pengetahuannya melewati beberapa tahapan, antara lain: 1) tahu (know), artinya recall memori yang telah ada sebelumnya setelah mengamati sesuatu, dengan menggunakan $5 \mathrm{~W}+1 \mathrm{H}$, 2) memahami (comprehension), individu mampu menginterpretasi, 3) aplikasi (application), individu mampu mengimplementasi, mengaplikasikan dan menerapkan dengan baik dan benar, 4) analisis (analysis), individu mampu memaparkan serta menganalisis hubungan satu dengan yang lain, 5) sintesis (synthesis), individu mampu menyatukan inti sari, meringkas dari rangkuman, 6) evaluasi (evaluation), individu mampu menjadikan sebuah bahan refleksi pada akhir kesimpulan. (Notoatmodjo dalam Nurkhayati, 2014).

Pengetahuan keluarga dengan kategori pengetahuan yang cukup, dilatar belakangi oleh beberapa faktor. Berdasarkan suatu gagasan yang menyatakan bahwa penentu tinggi rendahnya pengetahuan adalah umur (Wawan, 2011), sehingga pada hasil analisis pengetahuan keluarga yang cukup, bisa disebabkan oleh usia responden yang sebagian besar adalah dewasa madya.

Latar belakang lain yang menjadikan pengetahuan keluarga dikategorikan pengetahuan yang cukup, bisa dengan kontribusi pengalaman caregiver keluarga dalam melakukan 
perawatan. WHO (World Health Organization) dalam Notoatmodjo (2007) memberikan penjelasan tentang teori bahwa sebuah ilmu kesehatan dapat dijabarkan melalui pengetahuan yang dia didapatkan dari pengalaman. Yusuf (2015) menjelaskan bahwa pengetahuan seseorang bisa meliputi fakta-fakta berupa kabar dan dari pengalaman ketika individu tersebut menghadapi fenomena yang ada. Studi penelitian oleh Stanley et al. (2014) menyimpulkan bahwa secara statistik ada hubungan korelasi yang signifikan antara pengetahuan dengan pengalaman keperawatan (caregiver). Hal-hal ini yang bisa melatar belakangi hasil analisis pengetahuan keluarga dikategorikan dengan pengetahuan yang cukup.

\section{Efikasi Diri Caregiver Keluarga}

Hasil analisis univariat efikasi diri keluarga dapat dilihat pada Tabel 3.

Tabel 3. Analisis Univariat Efikasi Diri Keluarga

\begin{tabular}{clcc}
\hline No & $\begin{array}{c}\text { Efikasi Diri } \\
\text { Keluarga }\end{array}$ & Frekuensi & $\begin{array}{c}\text { Persentase } \\
(\mathbf{\%})\end{array}$ \\
\hline 1 & $\begin{array}{l}\text { Efikasi Diri } \\
\text { Tinggi }\end{array}$ & 23 & 24,2 \\
2 & $\begin{array}{l}\text { Efikasi Diri } \\
\text { Sedang }\end{array}$ & 53 & 55,8 \\
3 & $\begin{array}{l}\text { Efikasi Diri } \\
\text { Rendah }\end{array}$ & 19 & 20 \\
\hline \multicolumn{1}{c}{ Jumlah } & 95 & 100 \\
\hline
\end{tabular}

Pembahasan tentang efikasi diri caregiver keluarga pada pasien gangguan jiwa yang di dalamnya mencakup aspek merawat pasien defisit perawatan diri, merawat pasien harga diri rendah, merawat pasien isolasi sosial atau menarik diri, merawat pasien halusinasi, merawat pasien perilaku kekerasan atau marah, melakukan pengobatan dan terapi psikososial di RSJD Dr. RM. Soedjarwadi adalah sebagian besar keluarga memiliki efikasi diri dengan kategori sedang.
Terdapat kutipan di dalam buku yang ditulis oleh Pajares (2006) memaparkan pendapat tentang keyakinannya (selfefficacy) bahwa setiap pemuda memegang kemampuan untuk sukses dan berkekuatan penting dalam berusaha hingga akhirnya mencapai kesuksesan atau kegagalan yang mereka capai dalam usaha.

Efikasi diri caregiver keluarga dengan kategori efikasi diri sedang, dilatar belakangi oleh beberapa faktor. Faktor yang pertama adalah usia responden. Bandura dalam Karimah (2016) memaparkan bahwa salah satu faktor penentu dari tinggi rendah tingkat efikasi diri pada individu bisa dari kondisi fisik dan emosional. Pada sebagian besar responden penelitian ini adalah responden dengan kondisi fisik dan emosional dengan usia dewasa madya. Selanjutnya dengan pendapat yang sama adalah pada studi penelitian Chong et al. dalam Podkova (2013) menyatakan bahwa ada korelasi signifikan efikasi diri dengan umur seseorang.

Faktor berikutnya yang melatar belakangi kategori efikasi diri dengan sedang adalah dari pengalaman lama caregiver keluarga merawat pasien gangguan jiwa. Salah satu sumber penentu tinggi rendahnya tingkat efikasi diri adalah penguasaan pengalaman (mastery experiences) (Alwisol dalam Anggai, 2015). Sebuah studi penelitian yang di buat oleh Stanley et al. (2014) dengan judul relationship between knowledge, attitudes and self-eficacy of nurses in the management, menghasilkan pendapat yang sama.

\section{Analisis Bivariat \\ Hubungan Pengetahuan dengan Efikasi Diri}

Hasil analisis bivariat hubungan pengetahuan dengan efikasi diri dapat dilihat pada Tabel 4 . 
Tabel 4. Crosstabs Dan Uji Spearman Rank (Rho) Pengetahuan dengan Efikasi Diri

\begin{tabular}{|c|c|c|c|c|c|c|c|c|}
\hline \multirow[t]{3}{*}{ Pengetahuan } & \multicolumn{6}{|c|}{ Efikasi Diri } & \multirow[t]{3}{*}{$\overline{\mathbf{Z}_{\text {hitung }}}$} & \multirow{3}{*}{$\begin{array}{c}\text { p- } \\
\text { value }\end{array}$} \\
\hline & \multicolumn{2}{|c|}{ Tinggi } & \multicolumn{2}{|c|}{ Sedang } & \multicolumn{2}{|c|}{ Rendah } & & \\
\hline & F & $\%$ & $\mathbf{F}$ & $\%$ & $\mathbf{F}$ & $\%$ & & \\
\hline Baik & 16 & 16,8 & 7 & 7,4 & 0 & 0 & & \\
\hline Cukup & 7 & 7,4 & 42 & 44,2 & 6 & 6,3 & 0,704 & 0,001 \\
\hline Kurang & 0 & 0 & 4 & 4,2 & 13 & 13,7 & & \\
\hline
\end{tabular}

Berdasarkan dari tabel crosstabs antar variabel penelitian di atas menunjukkan bahwa: 1) 16 responden memiliki pengetahuan yang baik dengan efikasi diri tinggi, 2) tujuh responden memiliki pengetahuan yang baik dengan efikasi diri sedang, 3) tidak ada responden memiliki pengetahuan yang baik dengan efikasi diri rendah, 4) tujuh responden memiliki pengetahuan yang cukup dengan efikasi diri tinggi, 5) 42 responden memiliki pengetahuan yang cukup dengan efikasi diri sedang, 6) enam responden memiliki pengetahuan yang cukup dengan efikasi diri rendah, 7) tidak ada responden memiliki pengetahuan yang kurang dengan efikasi diri tinggi, 8) empat responden memiliki pengetahuan yang kurang dengan efikasi diri sedang, 9) 13 responden memiliki pengetahuan yang kurang dengan efikasi diri rendah. Pada bagian $\mathrm{z}$ hitung berdasarkan hasil uji korelasi spearman rank (rho) menunjukkan bahwa dengan banyak responden berjumlah 95 orang didapatkan nilai correlation coefficient atau disebut dengan kekuatan korelasi bernilai 0.704 dan nilai signifikasi probabilitas variabel pengetahuan dengan efikasi diri adalah 0.001 .

Pembahasan dari hasil olah data penelitian hubungan pengetahuan dengan efikasi diri pada caregiver keluarga pasien gangguan jiwa di RSJD Dr. RM. Soedjarwadi adalah terdapat hubungan korelasi yang signifikan tentang pengetahuan dengan efikasi diri pada caregiver keluarga pasien gangguan jiwa di RSJD Dr. RM. Soedjarwadi. Hal ini dibuktikan dengan hasil uji korelasi spearman rank (rho) dengan nilai correlation coefficient atau disebut kekuatan korelasi menunjukkan angka 0.704. Semakin baik pengetahuan maka semakin tinggi efikasi diri. Selanjutnya, nilai signifikan variabel pengetahuan dengan efikasi diri adalah 0.001 . Berdasarkan hal ini, maka secara statistik disimpulkan antar variabel memiliki hubungan atau adanya hubungan korelasi yang signifikan, karena secara statistik nilai probabilitas di bawah atau kurang dari $p$ value $(0.05)$.

Hasil uji korelasi antar variabel di atas memiliki pendapat yang sama dengan sebuah studi penelitian yang dilakukan oleh Stanley et al. (2014) menyimpulkan bahwa secara statistik ada hubungan korelasi yang signifikan antara pengetahuan dengan efikasi diri pada pengelolaan sakit pediatrik. Hasil yang serupa juga ada pada penelitian Podkova (2013) menyimpulkan bahwa secara statistik ada hubungan korelasi yang signifikan antara pengetahuan dengan selfefficacy pada pengelolaan gangguan jiwa.

Penelitian lain yang berkaitan dengan penelitian ini adalah penelitian oleh Carpinello et al. (2016) yang menghasilkan bahwa adanya analisis korelasi yang positif berkaitan dengan hasil ukur self-efficacy di antara orangorang yang menangani gangguan jiwa dalam melakukan caregiver atau tentang kemampuan mereka dalam mengatasi halhal yang mempengaruhi hidup pasien gangguan jiwa.

Pada hasil penelitian lain yang memiliki pendapat serupa adalah penelitian yang dilakukan oleh Hastings et 
al. (2002). Pada penelitian tersebut menyimpulkan bahwa self-efficacy telah diidentifikasi dalam literatur bahwa sebagai variabel penting yang dapat mempengaruhi perilaku orang tua, ditunjukkan dengan adanya bukti bahwa efikasi diri memediasi atau memberikan efek dari perlakuan caregiver.

Selanjutnya penelitian oleh Cheung et al. (2000) yang melakukan penelitian di Hong Kong, menjelaskan bahwa dari penelitiannya dapat disimpulkan dalam studi ini analisis regresi menunjukkan self-efficacy residualized merupakan prediktor kuat dari variabel kesehatan mental. Baik fungsional maupun struktural, terutama dimediasi oleh selfefficacy.

\section{KESIMPULAN}

1. Pengetahuan caregiver keluarga pasien gangguan jiwa di RSJD Dr. RM. Soedjarwadi adalah cukup.

2. Efikasi diri caregiver keluarga pasien gangguan jiwa di RSJD Dr. RM. Soedjarwadi adalah sedang.

3. Ada hubungan pengetahuan dengan efikasi diri pada caregiver keluarga pasien gangguan jiwa di RSJD Dr. RM. Soedjarwadi.

\section{DAFTAR PUSTAKA}

Anggai, AI., 2015, Hubungan Antara Efikasi Diri dengan Perilaku Berisiko Terhadap Kesehatan Pada Remaja, Skripsi, Universitas Muhammadiyah Surakarta, Surakarta.

Ali, Z., 2010, Pengantar Keperawatan Keluarga, EGC, Jakarta.

Azwar, A dan Prihartono, J., 2014, Metodologi Penelitian Kedokteran \& Kesehatan Masyarakat, Binarupa Aksara, Tangerang Selatan.

BPS Prov. Jawa Tengah., 2016, Profil Tempat Tinggal Jawa Tengah, CV. Pelita, Jawa Tengah.

Carpinello, SE., Knight, EL., Markowitz, FE. dan Pease, EA., 2016, The development of the Mental Health Confidence Scale: A measure of self-efficacy in individuals diagnosed with mental disorders, Psychiatric Rehabilitation Journal.

Cheung, S., Sun., dan Stephen, YK., 2000, Effects of Self-Efficacy and Social Support On The Mental Health Conditions of Mutual-Aid Organization Members. Social Behavior and Personality: an international journal. Scientific Journal Publishers.

Dewi, KS., 2012, Buku Ajar Kesehatan Mental, Lestari Mediakreatif, Semarang.

Gordon, JA., 2010, National Institute of Mental Health. https://www.nimh.nih.gov/index.shtml, diakses pada tanggal 24 Oktober 2016. 
Hastings, RP. dan Brown, T., 2002, Behavior Problems of Children With Autism, Parental Self- Efficacy, and Mental Health, American Journal on Mental Retardation, University of Southampton (United Kingdom).

Hurlock, EB., 1990, Psikologi Perkembangan: suatu pendekatan sepanjang rentang kehidupan, Erlangga, Jakarta.

Jalaluddin., 2013, Filsafat Ilmu Pengetahuan, Rajawali, Jakarta.

Karimah, NU., 2016, Hubungan Antara Efikasi Diri dengan Intensi Berwirausaha pada Mahasiswa Fakultas Psikologi Universitas Muhammadiyah Surakarta, Skripsi, Universitas Muhammadiyah Surakarta, Surakarta.

Kemenkes., 2013, Riset Kesehatan Dasar, Badan Penelitian Kesehatan Nasional. Jakarta.

Keyes, C., Dhingra, S. dan Simoes, EJ., 2010, Change in Level of Positive Mental Health as a Predictor of Future Risk of Mental Illness. Mental Health Promotion and Protection, American Journal of Public Health.

Notoatmodjo, S., 2007, Promosi Kesehatan dan Ilmu Perilaku, Rineka Cipta, Jakarta.

Notoatmodjo, S., 2010, Metodologi Penelitian Kesehatan, Rineka, Jakarta.

Nurhayati, E., 2016, Integrasi Perspeltif Psikologi Islam dalam Memahami Kepribadian Perempuan dan Laki-laki, Naskah Publikasi Universitas Muhammadiyah Surakarta.

Nurkhayati, A., 2014, Hubungan Antara Pengetahuan Ibu Tentang ASI Eksklusif dengan Motivasi Pemberian ASI Eksklusif, Skripsi, Universitas Muhammadiyah Surakarta, Surakarta.

Pajares, F. dan Tim Urdan., 2006, Self-Efficacy Beliefs of Adolescents, Age Publishing, Greenwich.

Perez, JML., Medina, FJ dan Munduate, L., 2011, Effects of Self-Efficacy on Objective and Subjective Outcomes in Transactions and Disputes, University of Seville, Spain.

Podkova, M., 2013, Correctional Officer's Knowledge of Mental Illness and Its Relationship With Self-Efficacy, Dissertation, Antioch University, New England.

Stanley, M. dan Pollard, D., 2014, Relationship Between Knowledge, Attitudes and Self-Efficacy of Nurses in Management of Pediatric Pain. Pediatric Nursing Knowledge and Attitude Survey Regarding Pain, Journal Publish US National Library of Medicine National Institutes of Health. 
Wakhid, A., 2013, Penerapan Terapi Latihan Keterampilan Sosial pada Klien Isolasi Sosial dan Harga Diri Rendah dengan Pendekatan Model Hubungan Interpersonal Peplau Di RS DR Marzoeki Mahdi Bogor, Jurnal Keperawatan Jiwa, Bogor.

Wawan, A., 2011, Teori dan Pengukuran Pengetahuan, Sikap dan Perilaku Manusia, Nuha Medika, Yogyakarta.

Womble, DM., 2015. Introductory Mental Health Nursing. China: Wolters Kluwer.

Wulansih, S. dan Widodo, A., 2008, Hubungan Antara Tingkat Pengetahuan dan Sikap Keluarga dengan Kekambuhan Pada Pasien Skizofrenia Di RSJD Surakarta, Jurnal Publikasi Ilmiah, Berita Ilmu Keperawatan.

Yaqin, TF., 2015, Hubungan Pengetahuan Keluarga Tentang Tanda dan Gejala Skizofrenia Paranoid Dengan Upaya Mencegah Kekambuhan Pasien Di RSJD Surakarta, Skripsi, Universitas Muhammadiyah Surakarta, Surakarta.

Yusuf, SF., 2015, Metodologi Penelitian Kesehatan, Darmais Press, Padangsidimpuan.

Zakeri, A., Rahmany, R dan Labone, E., 2016, Teachers' Self- and Collective Efficacy: The case of Novice English Language Teachers, Journal of Language Teaching and Research, Academy Publication. 